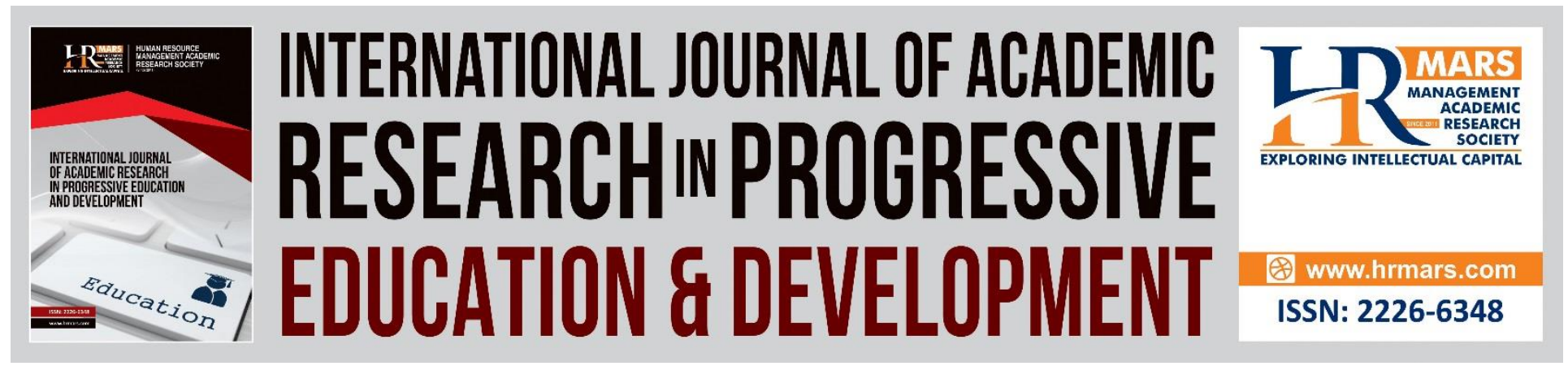

\title{
The Relationship between Demographic Factors and Intention to Apply for Career Promotion Among Teachers in Malaysia
}

Mohamad Ibrani Shahrimin Adam Assim, Salina Janis, Yasmin Yaccob, Nurul Hidayu Mat Jusoh

To Link this Article: http://dx.doi.org/10.6007/IJARPED/v9-i4/8060

DOI:10.6007/IJARPED/v9-i4/8060

Received: 08 October 2020, Revised: 03 November 2020, Accepted: 19 December 2020

Published Online: 31 December 2020

In-Text Citation: (Assim et al., 2020)

To Cite this Article: Assim, M. I. S. A., Janis, S., Yaccob, Y., \& Jusoh, N. H. M. (2020). The Relationship between Demographic Factors and Intention to Apply for Career Promotion Among Teachers in Malaysia. International Journal of Academic Research in Progressive Education and Development, 9(4), $204-220$.

Copyright: (C) 2020 The Author(s)

Published by Human Resource Management Academic Research Society (www.hrmars.com)

This article is published under the Creative Commons Attribution (CC BY 4.0) license. Anyone may reproduce, distribute, translate and create derivative works of this article (for both commercial and non-commercial purposes), subject to full attribution to the original publication and authors. The full terms of this license may be seen at: http://creativecommons.org/licences/by/4.0/legalcode

Vol. 9(4) 2020, Pg. 204 - 220

http://hrmars.com/index.php/pages/detail/IJARPED

JOURNAL HOMEPAGE

Full Terms \& Conditions of access and use can be found at

http://hrmars.com/index.php/pages/detail/publication-ethics 


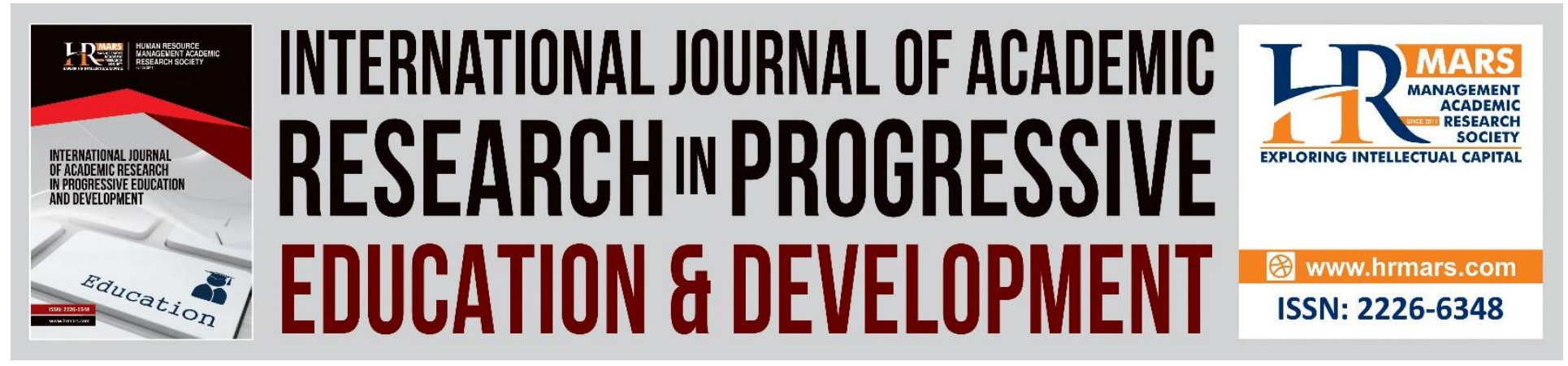

\title{
The Relationship between Demographic Factors and Intention to Apply for Career Promotion Among Teachers in Malaysia
}

\author{
Mohamad Ibrani Shahrimin Adam Assim, Salina Janis, \\ Yasmin Yaccob, Nurul Hidayu Mat Jusoh \\ Faculty of Humanities, Management and Science, Universiti Putra Malaysia \\ Bintulu Campus, Sarawak, Malaysia \\ Email: ibrani@upm.edu.my
}

\begin{abstract}
This study examined the relationship between demographic factors and the intention of teachers in applying for promotion. Demographic factors and gender were correlated with the dependent variable of intention to apply for promotion. A correlational study design was employed to determine the relationship among the variables that ascertain any prediction towards intention to apply for promotion. A total number of 226 of male and 274 female teachers were sampled among those who are qualified to apply for promotion. This study had shown that gender does moderate relationship among the study's independent variables and the dependent variable. For teachers in Malaysia, the intention to apply for promotion will increase if expectation of others towards applying for promotion also positively increase. There is a need for the educational sector to examine the influence of the demographic factors of gender in the appraisals on career development of teachers in Malaysia.

Keywords: Intention, Malaysian Teachers, Demographic Factors, Gender and Promotion.
\end{abstract}

\section{Introduction}

The turn of the new century had witnessed a greater sense gender sensitization, as men and women are free to engage in their careers and mutual support career development regardless of gender aspects and it also showed that women were actively involved in career development (See, 2007). Thus, in applying these aspects from the role congruity framework, men and women are guided by the opportunity structure according to gender role in achieving the vision and goals of individuals (Evan and Diekman, 2009). Furthermore, an increasing body of literature suggest that traditional gender belief influence differences in term of career matter. (Betz \& Fitzgerald, 1987; Evan and Diekman, 2009; Cassie \& Chen, 2012). In 2013, the total number of teachers in primary and secondary schools in Malaysia was about 418,146 and out of $31.7 \%$ are male and the rest are females (MOE, 2013). In line with this gender-related phenomenon, together with the majority of the teachers involved in education are women, this study was conducted to 
ascertain the gender factor on its role as a moderator within the intention to apply for promotion, as per ascribed within the framework of TPB by Ajzen (1991). Literature in career advancement within Malaysian education system is predominantly involving teachers (MOE, 2013). In relation to the factor of attitude towards applying for promotion in the study of career development of women by Giles and Lamour (2000), the authors identified six consequences in applying for promotion that are enhanced job satisfaction, increased salary, enhanced job security, extra responsibility and increased personal stress or pressure. The current study examined the relationship between the demographic factor of gender pertaining to performance appraisal system in influencing behavioral intentions of teachers in applying for promotional opportunities.

\section{Literature Review}

Many studies have applied the theory of planned behavior in predicting behavioral intention and thus predict actual behavior. Theory of planned behavior is an extension of the theory of reasoned action with the efforts made by Ajzen in the process of improving the prediction of behavior and behavioral intentions. In our efforts to further improve the theory of reasoned by Ajzen, he has highlighted the theory of planned behavior in addressing limitations when faced with behavior control by individual (Ajzen, 1991). Perceived behavior control was added to the theory of planned behavior, with the aim to deal with personal deficiencies and external obstruction (Giles \& Larmour, 2000).

Hoque, Abdul Razak and Zohora (2012), from the discussions and interviews with excellent teachers and those who are eligible to apply for excellent teacher (ET) positions, believed there are a few factors to be the source that hinder the intention of many teachers who are qualified to apply for the post of excellent teachers. Firstly, it was due to the fact that excellent teachers cannot return to the previous post as regular teacher. Secondly, because of relocation factor that demands them to move according to the needs of the education ministry. However, those factors were not based on empirical studies.

From the study by Giles and Lamour (2000), the authors found that employees attitude gave positive reaction towards applying for promotion but unlikely intend to apply for promotion although there is an opportunity for them. Moreover, based on the role congruity theory, women who work in places that are dominated by men will have the potential to suffer from stress at work (Eagly \& Karau; Shirom, Gilboa, Fried and Cooper, 2008). However, teaching profession has been known as a profession that was dominated worldwide by females (Giles \& Larmour, 2000).

Another factor employed in the current study is subjective norm. In the current study, subjective norm refers to social environment pressure that could influence the behavior of an individual (Ajzen, 2011). The variable of expectation of others towards applying for promotion represents the subjective norm in the framework of the study. From career development aspect such as promotion they are four referent that include the expectation from supervisor, colleagues, close friends, and family (Giles \& Larmour, 2000). Individual believed towards those social environment expectations from others around them, influence them to act certain behavior such as applying 
for promotion in career development point of view. Social environment pressure does have important role in convincing a certain behavior or intention to be executed by the individual. Moreover, it has been postulated that gender norms and socialization are among the few environmental factors in a society that greatly influences the choice of individual goals (Evan \& Diekman, 2009). Furthermore, Motulsky (2010) extend the arguments viewing a career change through the social context. Motulsky (2010) emphasize that career change will combine the ideas of culture and gender on careers, success and achievement, security, and change, in which women may face with inequality within cultural expectations. Thus, women have sacrificed career opportunities such as promotion success due to the family and this factor affect the development of their careers because women often seek a balance between work and career (Dolan, Bejarano and Tzafir, 2011).

Perceived behavior control refers to people perception of the ease or difficulty of performing the behavior of interest (Ajzen, 1991). Ajzen (1991) mentioned that Atkinson's (1964) theory of achievement motivation almost similar to perceived behavioral control. Controllability also being said as one of two distinct comprised in perceived behavioral control (Schreurs, Derous, Hooft, Proost, \& Witte, 2009). It refers to perceived control towards environmental factors and external resources. Various research were conducted to highlight the importance of justice and procedural fairness of a performance appraisal system such as by Tan \& Lau (2012) provide evidence of indirect relationship between financial measures and organizational commitment and mediated by fairness in performance evaluation procedure and job satisfaction. The current study explored the compatibility of selected variable from career development indicator specifically performance appraisal system as a control belief factor in theory of planned behavior that may affect intention to apply for promotion. Pooyan and Eberhardt (1990), emphasize that when supervisors treat their employees equally regardless of gender, the same perception regarding performance appraisal system will be similarly applied. Geddes and Konrad (2003) furthers the argument by referring to the result of their study which shown a positive beta weight which indicated that female workers react positively compared to male workers toward performance appraisal system.

Furthermore, Ajzen (1991) also emphasized on perceived behavioral control is more compatible to self-efficacy by Bandura $(1977,1987)$. Motives of individual behavior can be influenced by the self-efficacy belief, as well as its impact on the development and subsequent patterns of thought and emotional reaction. The constructs of self-efficacy belief or perceived behavior control in theory of planned behavior were describes within general framework of the relationships between beliefs, attitudes, intentions, and behavior. In the study of extended theory of planned behavior in testing psychological variables mediate sex differences in alcohol consumption by Zimmermann and Sieverdeng (2011), the construct of self-efficacy was applied as one of the variable as the concept of perceived behavioral control related to the concept of self-efficacy by Bandura (1977). Schreurs et al (2009), emphasized that controlliability reflect individual perceived control towards external resources while self-efficacy individual perceived control over internal resources. To be more precise in predicting intention behavior within career development field, study by Sandler (2000) incorporating the construct of career decision making 
self-efficacy in the theory of planned behavior. Literature had consistently identified the factors that cause women to decide not to apply for promotion, which include lack of aspiration, less conscious about system of promotion, no confidence, socialization based on gender, fear of failure, and no desire to compete (Acher 1989; Limerick and Anderson 1999; Coffey and Delemont 2000; Oplatka and Tamir, 2009). In determining teacher's intention to apply for promotion, this study applied Theory of Planned Behavior to investigate between the independent and dependent variables. When an individual behavior intention is said to be high it will be likely to perform the behavior if complied with the general requirements of theory of planned behavior that are greater the attitude, subjective norm, and perceived behavioral control.

In line with the worldwide gender-related phenomena, together with the majority of the teachers involved in education are women, the current study examined and investigated on gender influences as moderating effect in predicting the intention to apply for promotion among the excellent teachers candidate.

\section{Methodology}

This study employed a correlational study to determine the relationship among the variables. In addition, this study attempted to gauge potential predictors toward intention to apply for promotion with, the application of theory of planned behavior as the major measurable constructs. Variables selected in this study were intended to provide a deeper understanding in career development. By adding the demographic factor of gender as a moderator, this study attempted to examine the role of gender in the relationship between the measured independent and dependent variables. Participants of the survey conducted in the current study involved teachers who are qualified to apply for a promotion within their teaching service scheme. Constructing of items in the questionnaire was based on the study by Giles and Lamour (2000), Giles, Findley, \& Field (1997) and Taylor and Betz (1983). Dichotomous variable was used to assess gender, 0 represent male and 1 represent female. A total of 14 items were used in the study and modified to suit for sampled teachers. All items were measured using 7-point Likertscales ranging from disagree to most agree.

In this study confirmatory factor analysis (CFA) were used as primary examination on the instrument. Through confirmatory factor analysis this study may had attempted to extrapolate the findings of examining the construct validity of the sampled instrument items. Hence, for this purpose, SPSS and AMOS programs were used extensively to analyze the psychometric data gathered. Confirmatory factor analysis (CFA) was carried out to determine the degree of model fit, the explained variances and standardized residual for the measurement variables, and the adequacy of the factor loadings. "specifically, and item was assigned to a factor when its loading was at least twice its standard error" (Landis, Beal \& Tesluk, 2000). According to the results of CFA for each latent variable, items that they had low factor loading (at least .50), were dropped (Hair et al., 2006). The main purpose of this study was to investigate the moderator effect of a demographic factor of gender towards relationship between independent variables and dependent variable. To achieve this objective, a multigroup analysis was conducted to investigate 
Vol. 9, No. 4, 2020, E-ISSN: $2226-6348$ @ 2020 HRMARS

relationship between predictors variables that were ATAP, EOTAP, CDMSE and BTPAS towards ITAP. Multigroup modeling for males and females for measurement model and multigroup path analysis were conducted. The current study also compared the results between structured model of female and male to determine whether gender does or does not moderate the relationship. The result of the standardized regression weight by both genders was determined and described the moderator effect and strength of relationship between the variables of the study.

\section{Results}

\section{Measurement Model}

The purpose of the evaluation of measurement model in this study was to examine the measurement properties of the observed variables. Result in measurement model 1 had included all item in the study.

Table 1.

Computation of Degree of Freedom and Chi-Square Statistics for Goodness-of Fit

$\begin{array}{llll}\overline{\text { Model }} \quad \text { NPAR CMIN } & \text { DF } & P & \text { CMIN/DF }\end{array}$

Unconstrained

$44 \quad 599.152$

109.000

5.497

Table 2.

Incremental Fit Indices 


$\begin{array}{llllll}\text { Model NFI RFI IFI TLI CFI RMSEA } & \end{array}$

Table 1 above shows that there are 44 parameters to be estimated with 109 (153-44) degree of freedom and yielded a significant chi-square value, $\chi^{2}$ value of 599.152. Table 2 shown the baseline comparisons fit indices of NFI, RFI, IFI, TLI and CFI are greater than .9 (range:.910 to .940 ), thus indicate that the model fit the data well. RMSEA values for this model is .095 that indicate mediocre fit as suggested by $\mathrm{Ho}$ (2006). In this research, we determined to investigate the role of gender as moderator between the dependent variable and independent variable. Thus, it is important to test if the factor structured by the measurement model is the same for males and females. We conducted a multigroup analysis for measurement model to examine if there are any differences in terms of factor structured for males and females in the measurement model.

This study adapted CFI differences to test for measurement invariance with the CFI difference value of below .05 as a guideline. Littlle1997; Marcoulides et al. 2008; Raykov and Marcolides 2006) as cited by Qureshi and Compeau (2009) suggested that a nonsignificant difference in $\chi^{2}$ and CFI below 0.05 indicates model invariance. In this study the value of CFI difference between the group invariant and group variant is .015 but $\chi^{2}$ value shown a significant different.

\section{Table 3.}

\section{Computation of Degree of Freedom and Chi-Square Statistics for Goodness-of Fit}


INTERNATIONAL JOURNAL OF ACADEMIC RESEARCH IN PROGRESSIVE EDUCATION AND DEVELOPMENT

Vol. 9, No. 4, 2020, E-ISSN: $2226-6348$ @ 2020 HRMARS

$\begin{array}{llllllll}\text { Group Invariant } & & & 71 & 1268.251 & 235 & .000 & 5.397 \\ \text { Group Variant } & 88 & 1112.441 & 218 & .000 & 5.103 & \end{array}$

Table 4.

Incremental Fit Indices

$\begin{array}{llllll}\text { Model NFI } & \text { RFI IFI TLI CFI RMSEA AIC }\end{array}$

Table 5.

Nested Model Comparison

$\begin{array}{llllllll}\text { Model } & \text { DF } & \text { CMIN } & P & \text { NFI } & \text { IFI } & \text { RFI } & \text { TLI }\end{array}$


\begin{tabular}{llllllllll}
\hline Group Invariant & & 17 & 155.810 & .000 & .017 & .017 & .009 & .009
\end{tabular}

The critical ratio test gender differences for the regression weight. From the test, 10 of the pairwise comparisons between males and females (m1-f1, m13-f13, m12-f12, m8-f8, m14$\mathrm{f14}, \mathrm{m} 15-\mathrm{f15}, \mathrm{m2}-\mathrm{f2}, \mathrm{m5}-\mathrm{f5}, \mathrm{m6}-\mathrm{f6}, \mathrm{m3}-\mathrm{f3})$ are significant $(> \pm 1.96, \rho<.05)$.

Note for models: Two data set were used in this multigroup analysis. Each consisting of 12 measurement variables. For the group Invariant model, there are 82 parameters to be estimated. This model has 224 (306-82) degree of freedom with a significant chi-square value, $\chi^{2}=1161.995$, $\rho<.05$. For the group invariant model, there are 88 parameters to be estimated. This model has 218 (306-88) degree of freedom with a significant chi-square value, $\chi^{2}=1150.539, \rho<.05$. Summary of the models: Table 3.2.3(a-c) consisted of chi-square goodness-of-fit statistic, baseline comparisons fit indices, and model comparison statistic for the group invariant and group variant measurement model.

Table 6.

Computation of Degree of Freedom and Chi-Square Statistics for Goodness-of Fit

$\begin{array}{llll}\text { Model NPAR CMIN DF P CMIN/DF } & \text { D }\end{array}$

\begin{tabular}{llllllll}
\hline Group Invariant & & 82 & 1161.995 & 224 & .000 & 5.187 \\
Group Variant & 88 & 1150.539 & 218 & .000 & 5.278 &
\end{tabular}

Table 7.

Incremental Fit Indices 
INTERNATIONAL JOURNAL OF ACADEMIC RESEARCH IN PROGRESSIVE EDUCATION AND DEVELOPMENT

Vol. 9, No. 4, 2020, E-ISSN: $2226-6348$ @ 2020 HRMARS

\begin{tabular}{|c|c|c|c|c|c|c|c|}
\hline Model & & NFI & RFI & IFI & TLI & CFI & RMSEA AIC \\
\hline Group Invariant & & .884 & .860 & .905 & .884 & .904 & 1325.995 \\
\hline Group Variant & .886 & .857 & .905 & .881 & .905 & .093 & 1326.539 \\
\hline
\end{tabular}

Table 8.

Nested Model Comparison

\begin{tabular}{lllllllll}
\hline Model & DF & CMIN & $P$ & NFI & IFI & RFI & TLI \\
\hline
\end{tabular}

Figure 1 shows that among all four path that link Intention to Apply for Promotion (ITAP), only Expectation of Others towards Applying for Promotion (EOTAP) and Belief towards Performance Appraisal System (BTPAS) has significant association towards ITAP. The positive direction indicates that the higher the association with EOTAP, the higher the increase of the Intention among Teachers to Apply for Promotion $(\beta=.589)$. BTPAS were found has a little association towards ITAP $(\beta=.008)$. Nonetheless, the other two indicators; ATAP $(\beta=.27)$, CDMSE $(\beta=.164)$ and, were found not significantly supported in teachers Intention to Apply for Promotion. However, based on the result of the squared multiple correlation, the predictors of ATAP, EOTAP, 
INTERNATIONAL JOURNAL OF ACADEMIC RESEARCH IN PROGRESSIVE EDUCATION AND

DEVELOPMENT

Vol. 9, No. 4, 2020, E-ISSN: $2226-6348$ @ 2020 HRMARS

CDMSE and BTPAS are accounted for .884 or $88.4 \%$ of the variances of ITAP. Thus, this indicate that only .116 or $11.6 \%$ of the correlations was attributed for the unexplained variance for this model.

Structured Model for Multi Group

\begin{tabular}{|c|c|c|c|}
\hline \multirow{2}{*}{$\begin{array}{l}\text { Attitude towards applying for } \\
\text { promotion (ATAP) }\end{array}$} & & \multicolumn{2}{|l|}{.151} \\
\hline & .780 & \multirow[t]{2}{*}{.237} & \multirow[b]{2}{*}{.890} \\
\hline \multirow{2}{*}{$\begin{array}{l}\text { Expectation of others towards } \\
\text { applying for promotion (EOTAP) }\end{array}$} & .512 & & \\
\hline & & \multirow{3}{*}{\multicolumn{2}{|c|}{$\begin{array}{l}\text { Intention to apply for promotion } \\
\text { (ITAP) }\end{array}$}} \\
\hline $\begin{array}{l}\text { Career decision making self-efficacy } \\
\end{array}$ & .194 & & \\
\hline \multirow{2}{*}{$\begin{array}{l}\text { Belief towards performance appraisal } \\
\text { system (BTPAS) }\end{array}$} & -.166 & & \\
\hline & & \multicolumn{2}{|l|}{.456} \\
\hline
\end{tabular}

Figure 1: Result of Moderator Test of Gender on Relationship between Predictors and Intention to Apply for Promotion

Male

Female

Figure 1 shows the result of moderating effects relating to the predictors and intention to apply for promotion with testing the role of gender as the moderator between the independent and dependent variables. Figure 1 represent the standardized estimates of the test and the result of the path coefficient for all the predictors in the study according to gender of male and female teachers. Path coefficient result for variable of attitude towards applying for promotion in predicting intention to apply for promotion shows a nonsignificant result for male .151 versus for female .237. Expectation of others towards applying for promotion (EOTAP) in predicting intention to apply for promotion show a significance result between both genders. Both female and teachers the result of .780 and .512 indicate a slightly greater association among males' teachers compare to female teachers. For predictor of career decision making self-efficacy (CDMSE) the result shows a nonsignificant association by the predictor towards their intention in applying for promotion. With significant value of standardized regression weight of .166 for males and .45 for females it shown that female teachers have greater association between variable of belief towards performance appraisal system (BTPAS) and intention to apply for promotion (ITAP). However, based on the result of the squared multiple correlation, the predictors of ATAP, EOTAP, CDMSE and BTPAS for males' teachers are accounted for .890 or $89 \%$ of the variances of ITAP. Thus, this indicate that only .11 or $11 \%$ of the correlations was attributed for the unexplained variance for this model. While for female teachers the predictors of ATAP, EOTAP, CDMSE and BTPAS are accounted for .922 or $92.2 \%$ of the variances of ITAP. Thus, this indicate that only .078 or $7.8 \%$ of the correlations was attributed for the unexplained variance for this model. 


\section{Discussions}

The current study found that the variable Belief towards Performance Appraisal System (BTPAS) is a predictor of intention to apply for promotion. The moderate relationship of BTPAS and Intention to Apply for Promotion (ITAP) indicate that teachers belief towards the performance appraisal system that being used in the evaluation for the promotion application do influence the intention of Malaysian teachers to apply for promotion (for example the excellent teachers' post). The positive direction of relationship shows that the intention to apply for promotion might increase when their belief towards performance appraisal system is increasing. Thus, it is argued that the teacher's belief towards performance appraisal system can be one of the factors that contribute in motivate most of the qualified teacher for the post of excellent teachers to apply for the position.

From the study of Hoque, Razak and Zohora (2012), based on their interviewed information a few factors were found demotivate qualified teachers for the post of Excellent Teachers that are: 1) the Excellent Teachers were not allowed to return as regular teacher 2) they can be transferred as per requirement from the Ministry of Education. In line with these two factors, no further research was conducted to support the significance of the relationship towards the behavior. Hence, the current study included Belief towards Performance Appraisal System (BTPAS) as one of the predictors of intention to apply for promotion, thus indicate that BTPAS is one of the contributor in predicting intention to apply for promotion among teachers in Malaysia, in general.

The present finding has provided a strong support that gender do moderate the relationship between independent variables and intention to apply for promotion. Although there was a significant difference in the regression weight value between male and female the value for both genders, males were implied to be more concern of significant others or the societies' perception towards their career achievement. As assertedby Evans and Diekman (2009), career for males are perceived as facilitating improvement in their status goals. In other words, promotion can be seen as a positive achievement and will contribute in enhancing the male teachers' status in society. In another study by Dolan, Bejarano and Tzafrir (2011), when a comparison is made between women and men, women view the prospect of a career based on balance and security characteristic. The current study study found that attitude towards applying for promotion has a nonsignificant correlation with the dependent variable, as the male and female teachers were not affected of consequences in applying for promotion. The result for belief towards performance appraisal system also differ between the female teachers and male teachers. Female teachers were more affected to apply for promotion compared to the male counterparts. Their belief in performance appraisal system is positively affecting their intention to apply for promotion. In evaluation process for promotion, the teachers might not feel familiar with the system because of the confidentiality of the instrument used in assessing the candidate for promotion. Less information provided in the process of promotion evaluation might be one of the reasons in hindering teacher's intention to apply for promotion. However, when the teachers are more familiar of the appraisal system it will eventually motivate them to apply for promotion. It can be concluded that the increase of belief towards performance appraisal system might 
eventually motivate and increase both female and male teachers' intention to apply for promotion when there is opportunity. With the combination of structural equation modeling processes, this study had compared results between gender. It is concluded that gender do moderate the relationship between independent and dependent variable of this study.

\section{Conclusion}

Over the past years, the Ministry of Education has sought to elevate the teaching profession in Malaysia. The procedures involved in the promotion of teaching sector was recently upgraded for the continuing improvement purposes. It has been cited in various reports and studies that the time-based system in which promotion to be awarded was shortened from ten years to eight years of qualified services. Furthermore, teachers also had the options to apply for promotion within five years serving in their initial salary grade. Consequently, this option will eventually offer the teachers to cut short of the years to qualify for promotion from eight years to the minimum of five years. Hence, as a direct impact to these current practices of promotion procedures, teachers could apply for position of excellent teachers and other positions offered by the ministry. In line with these current changes in the human resource development of the teaching sector, this study had attempted to examine the relationship between potential predictors and the variable of intention to apply for promotion among teachers in Malaysia. The current study had also explored the moderator effect of gender in the relationship between various variables. From this study, teachers were found to be primarily influenced by two predictors, which are expectation of others towards applying for promotion, and belief towards applying for promotion. Therefore, it is feasibly postulated to suggest that teachers may benefit from the effort of Malaysia's government initiatives in enhancing career advancements via the Ministry of Education. Nonetheless, this study also determined that teachers should exert more attention and be more proactive in seeking information for their opportunities in career development. A large body of literature consistently suggest that positive career development and success in career advancement does had their implications on creating satisfaction in performing tasks, and therefore, will eventually contribute to the teaching profession. This study also indicate that teachers should realize that promotion opportunity was mainly, and constantly viewed as channelled for the teachers own benefit. Teachers are directly implicated as to not rely totally only by others' opinion, particularly on their capabilities, and specifically on the qualification to apply for their own promotion.

\section{Limitation and Study Forward}

The current study, as per suggested by the major findings, proposed that the current performance appraisal system administered by the Ministry of Education, to be systematically micro-reviewed and, to a certain extent, revised indefinitely, particularly within the various processes involving in awarding promotion for teachers. The most apparent implication of the current study may shed the need to explore the findings in which indicate that female teachers are more motivated to apply for promotion compared to male teachers. Moreover, pertinent findings on the increase of teacher's belief towards performance appraisal system such as the complexity of the system, openness of the system, had suggest that teachers will eventually increase their intentions to apply for promotion. Notwithstanding the main objective in 
introducing excellent teachers position was to enhance quality of teaching and learning process, some of the major implication of the current study on the policies involved are undeniably beneficial to all teaching sectors, particularly in Malaysian educational system. Nonetheless, more information is indeed required, particularly regarding the appraisal system. Thus, as per suggested in the findings, this may attract the interest among teachers especially female teachers to apply for their much-qualified promotions. Gender does play a role in the career development of male professionals. It is statistically postulated that for male teachers, the increase of their belief towards performance appraisal system itself would not be enough to motivate them to apply for promotion. It is further argued that the lack of encouragement from their environmental factors might cause them to lose opportunity to apply for their own promotion and career advancement opportunities. It would be worthwhile if any further study focuses on another categories of teachers within Malaysia or other countries in seeing the phenomenon of intention to apply for promotion and other self and social factors.

\section{Acknowledgement}

The author would like to acknowledge all teachers and individuals involved in the data gathering for their help and generous support.

\section{References}

Ajzen, I. (2011). The theory of planned behaviour: Reactions and reflections. Psychology and Health, 26(9), 1113-1127. https://doi.org/10.1080/08870446.2011.613995

Ansari, N., Moazzam, A., Jabeen, N., \& Salman, Y. (2016). Gender and Perceptions of Organizational Justice: A Study of University of the Punjab. Pakistan Journal of Women's Studies: Alam-e-Niswan, 23(1), 45-63.

http://search.proquest.com.ezp.waldenulibrary.org/docview/1805464427?accountid=14

872\%5Cnhttp://sfxhosted.exlibrisgroup.com/waldenu?url_ver=Z39.88-

2004\&rft_val_fmt=info:ofi/fmt:kev:mtx:journal\&genre=unknown\&sid=ProQ:ProQ\%3Asoc scijournals\&atitle $=$ GENDER+AND+

Armitage, C. J., \& Conner, M. (2010). Efficacy of the Theory of Planned Behaviour: A MetaAnalytic Review E Y cacy of the Theory of Planned Behaviour : A meta-analytic review. July 2017, 471-499. https://doi.org/10.1348/014466601164939

Betz, N. E., Klein, K. L., \& Taylor, K. M. (1996). Evaluation of a short form of the career decisionmaking self-efficacy scale. Journal of Career Assessment, 4(1), 47-57. https://doi.org/10.1177/106907279600400103

Betz, N. E., \& Luzzo, D. A. (1996). Decision-Making Self-Efficacy Scale. 413-428.

Blickenstaff, J. C. (2005). Women and science careers: Leaky pipeline or gender filter? Gender and Education, 17(4), 369-386. https://doi.org/10.1080/09540250500145072

Bozionelos, G., \& Bennett, P. (1999). The theory of planned behaviour as predictor of exercise: The moderating influence of beliefs and personality variables. Journal of Health Psychology, 4(4), 517-529. https://doi.org/10.1177/135910539900400406

Cabrera, G. A., Ann Christine Conde, C. L., \& Angela Ingles, K. S. (2019). Difficulties on Work-Life Balance of Married Career Women: The Case of Generation X. Asia Pacific Journal of Academic Research in Business Administration, 5(1), 16-21. 
INTERNATIONAL JOURNAL OF ACADEMIC RESEARCH IN PROGRESSIVE EDUCATION AND

DEVELOPMENT

Vol. 9, No. 4, 2020, E-ISSN: $2226-6348$ @ 2020 HRMARS

Cheng, C.-F., Chen, L. H., Chen, M.-Y., \& Lu, W.-C. (2012). Fan participation behaviour in baseball: An application of the theory of planned behaviour. International Journal of Sports Marketing \& Sponsorship, 14(1), 22-33. Retrieved from

http://people.umass.edu/aizen/abstracts/chen2012a.html

Cheung, F. M., \& Halpern, D. F. (2010). Women at the top: Powerful leaders define success as work + family in a culture of gender. American Psychologist, 65(3), 182193. https://doi.org/10.1037/a0017309

Conference, F. I. (2015). Social Factors and Women' S Career Advancement To Senior. 2001.

Conner, M., \& Norman, P. (2006). Predicting Health Behaviour: reseaarch and practice with social congnition model. Predicting Health Behaviour, 172-182.

Dolan, S. L., Bejarano, A., \& Tzafrir, S. (2011). Exploring the moderating effect of gender in the relationship between individuals' aspirations and career success among engineers in Peru. International Journal of Human Resource Management, 22(15), 3146-3167. https://doi.org/10.1080/09585192.2011.560883

Eagly, A. H., \& Karau, S. J. (2002). Role congruity theory of prejudice toward female leaders. Psychological Review, 109(3), 573-598. https://doi.org/10.1037/0033-295X.109.3.573

Evans, C. D., \& Diekman, A. B. (2009). On motivated role selection: Gender beliefs, distant goals, and career interest. Psychology of Women Quarterly, 33(2), 235-249. https://doi.org/10.1111/j.1471-6402.2009.01493.x

Geddes, D., \& Konrad, A. M. (2003). Demographic differences and reactions to performance feedback. Human Relations, 56(12), 1485-1513. https://doi.org/10.1177/00187267035612003

Giles, M., \& Larmour, S. (2000a). The theory of planned behavior: A conceptual framework to view the career development of women. Journal of Applied Social Psychology, 30(10), 2137-2157. https://doi.org/10.1111/j.1559-1816.2000.tb02429.x

Giles, M., \& Larmour, S. (2000b). The theory of planned behavior: A conceptual framework to view the career development of women. Journal of Applied Social Psychology, 30(10), 2137-2157. https://doi.org/10.1111/j.1559-1816.2000.tb02429.x

Giles, M., \& Rea, A. (1999). Short research note Career self-eY cacy : An application of the theory of planned behaviour. Journal of Occupational and Organizational Psychology, 393-398.

Giles, W. F., Findley, H. M., \& Feild, H. S. (1997). Procedural fairness in performance appraisal: Beyond the review session. Journal of Business and Psychology, 11(4), 493-506. https://doi.org/10.1007/bf02195894

Glanz, K., Rimer, B. k., \& Viswanath, K. (2002). Health and Health.

Gottman, J. M., Coan, J., Carrere, S., Swanson, C., Gottman, J. M., Coan, J., Carrere, S., \& Swanson, C. (1998). Predicting Marital Happiness and Stability from Newlywed Interactions Published by : National Council on Family Relations Predicting Marital Happiness and Stability from Newlywed Interactions. Journal of Marriage and Family, 60(1), 5-22. https://doi.org/10.1002/job

Guo, R., Berkshire, S. D., Fulton, L. V., \& Hermanson, P. M. (2019). Predicting intention to use evidence-based management among U.S. healthcare administrators: Application of the theory of planned behavior and structural equation modeling. International Journal of Healthcare Management, 12(1), 25-32. https://doi.org/10.1080/20479700.2017.1336856 
Hill, T., Smith, N. D., \& Mann, M. F. (1987). Role of Efficacy Expectations in Predicting the Decision to Use Advanced Technologies: The Case of Computers. Journal of Applied Psychology, 72(2), 307-313. https://doi.org/10.1037/0021-9010.72.2.307

Hoque, K. E., Ahmad Zabidi Abdul Razak, \& Zohora, M. F. (2012). ICT Utilization among School Teachers and Principals in Malaysia. International Journal of Academic Research in Progressive Education and Development, 1(4), 17-34.

Icek, A. (1991). The Theory of Planned Behavior Organizational Behavior and Human Decision Processes. Organizational Behavior and Human Decision Processes, 50(2), 179-211.

Jadidian, A., \& Duffy, R. D. (2012). Work volition, career decision self-efficacy, and academic satisfaction: An examination of mediators and moderators. Journal of Career Assessment, 20(2), 154-165. https://doi.org/10.1177/1069072711420851

Jimmieson, N. L., Peach, M., \& White, K. M. (2008). Utilizing the theory of planned behavior to inform change management: An investigation of employee intentions to support organizational change. Journal of Applied Behavioral Science, 44(2), 237-262. https://doi.org/10.1177/0021886307312773

Kautonen, T., Gelderen, M. Van, \& Tornikoski, E. T. (2012). theory of planned behaviour r Fo Pe er Re vi.

Landis, R. S., Beal, D. J., \& Tesluk, P. E. (2000). A Comparison of Approaches to Forming Composite Measures in Structural Equation Models. Organizational Research Methods, 3(2), 186-207. https://doi.org/10.1177/109442810032003

Leo Marcos, F., Sánchez Miguel, P., Sánchez Oliva, D., Gómez Corrales, F., \& García Calvo, T. (2009). Análisis de las relaciones existentes entre la orientación y el clima motivacional con los comportamientos antisociales en jóvenes deportistas. Revista Iberoamericana de Psicología Del Ejercicio y El Deporte, 4(1), 15-28.

McGinn, K. L., \& Oh, E. (2017). Gender, social class, and women's employment. Current Opinion in Psychology, 18, 84-88. https://doi.org/10.1016/j.copsyc.2017.07.012

Ministry of Education. (2016). Quick Facts 2016: Malaysia Educational Statistics. Quick Facts 2016, Malaysia Educational Statistics, 1-45. http://www.moe.gov.my

Models, N., An, I. (1999). Female Administrators and School-. 27(199910), 401-414.

Motulsky, S. L. (2010). Relational Processes in Career Transition: Extending Theory, Research, and Practice. The Counseling Psychologist, 38(8), 1078-1114.

https://doi.org/10.1177/0011000010376415

Oplatka, I., \& Tamir, V. (2009). "I don't want to be a school head": Women deputy heads' insightful constructions of career advancement and retention. Educational Management Administration and Leadership, 37(2), 216-238.

https://doi.org/10.1177/1741143208100299

Piper, H. (2005). AmandaCoffeySaraDelamontFeminism and the Classroom Teacher: Research, Praxis and Pedagogy2000Routledge/FalmerLondon and New York0-750-70749-6182pp. Teaching and Teacher Education, 21(5), 593-599.

https://doi.org/10.1016/j.tate.2005.03.011

Pooyan, A., \& Eberhardt, B. J. (1990). Predictors of Performance Appraisal Satisfaction: The Effect of Gender. Asia Pacific Journal of Human Resources, 28(1), 82-89.

https://doi.org/10.1177/103841119002800107 
Qureshi, I., \& Compeau, D. (2009). Assessing between-group differences in information systems research: A comparison of covariance- and component-based SEM. MIS Quarterly: Management Information Systems, 33(1), 197-214. https://doi.org/10.2307/20650285

Shirom, A., Gilboa, S. S., Fried, Y., \& Cooper, C. L. (2008). Gender, age and tenure as moderators of work-related stressors' relationships with job performance: A meta-analysis. Human Relations, 61(10), 1371-1398. https://doi.org/10.1177/0018726708095708

Smith, R. L., Karaman, M. A., Balkin, R. S., \& Talwar, S. (2020) Psychometric properties and factor analyses of the achievement motivation measure, British Journal of Guidance \& Counselling, 48:3, 418-429, DOI: 10.1080/03069885.2019.1620173

Tan, S., \& Lau, J. (2012). The Impact of Performance Measures on Employee Fairness Perceptions, Job Satisfaction andOrganisational Commitment. Journal of Applied Management Accounting Research, 10(2), 57-72.

Taylor, K. M., \& Betz, N. E. (1983). Applications of self-efficacy theory to the understanding and treatment of career indecision. Journal of Vocational Behavior, 22(1), 63-81. https://doi.org/10.1016/0001-8791(83)90006-4

Tellhed, U., Bäckström, M., \& Björklund, F. (2018). The role of ability beliefs and agentic vs. communal career goals in adolescents' first educational choice. What explains the degree of gender-balance? Journal of Vocational Behavior, 104(April 2017), 1-13. https://doi.org/10.1016/j.jvb.2017.09.008

Zimmermann, F., \& Sieverding, M. (2011). Do psychological variables mediate sex differences in young adults alcohol use? Substance Use and Misuse, 46(4), 552-559. https://doi.org/10.3109/10826084.2010.497179 